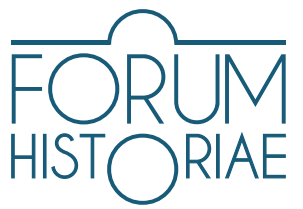

\title{
Places of Revolt: Geographical References in the Slovak Anarchist Press Around the Turn of the Millennium*
}

\author{
Ondřej Daniel
}

\begin{abstract}
DANIEL, Ondřej: Places of Revolt: Geographical References in the Slovak Anarchist Press Around the Turn of the Millennium.

Geographical references likely played a crucial role in shaping the worldview of Slovakia's anti-globalisation activists. The aim of this study is to provide a classification of geographical categories based on how they operate in the anti-globalisation activist press. The primary material for this study consists of two journals: Zdola ("From the Bottom") published by the Slovak section of the Czechoslovak Anarchist Federation, and Žerme bohatých ("Let's eat the rich") published by the organisation Priama akcia ("Direct action"), the Slovak section of the International Workers' Association. Geographical references in the Slovak anarchist press around the turn of the millennium provided potentially isolated activist communities with information about relevant struggles around the world. These references empowered these communities by calling on them to be a part of the global struggle. Three narrative strategies are identified: context, equation and inspiration. The differences between the two journals stem from their different ideological profiles. The qualitative research presented in this article allows for a semantic categorisation of these references.
\end{abstract}

Keywords: anti-globalisation movement, activist journals, Slovakia, anarchism, geographical references DOI: https://doi.org/10.31577/forhist.2020.14.1.4

W Then leafing through the different activist journals from a period of heightened discussions about globalisation ${ }^{1}$ around the turn of the millennium, the sheer number of geographical references in these do-it-yourself (DIY) media outlets is astonishing. The anti-globalisation movement of the late 1990s and early 2000s can be considered a truly global social movement, ${ }^{2}$ active not only in the core capitalist countries but also in more peripheral locations. ${ }^{3}$ The references to the global nature of the issue made in these journals connected local actors

\footnotetext{
* This work was supported by the European Regional Development Fund Project "Creativity and Adaptability as Conditions of the Success of Europe in an Interrelated World" (No. CZ.02.1.01/0.0/0.0/16_019/0000734). 1 BECK, Ulrich. What is Globalization? Cambridge : Polity Press, 1999.

2 DELLA PORTA, Donatella - DIANI. Mario. Social Movements. An introduction. Malden; Oxford; Carlton : Blackwell Publishing, 1998; FLESHER FOMINAYA, Cristina. Collective Identity in Social Movements: Central Concepts and Debates. In Sociology Compass, 2010, Vol. 4, No. 6, pp. 393-404, DOI 10.1111/j.17519020.2010.00287.x; KRIESI, Hanspeter - KOOPMANS, Ruud - DUYVENDAK, Jan Willem - GIUGNI, Marco G. New Social Movements in Western Europe: A Comparative Analysis. London : UCL Press, 2002; KATSIAFICAS, Georgy. The Subversion of Politics. European Autonomous Social Movements and the Decolonization of Everyday Life. Edinburgh; Oakland : AK Press 2006; NAVRÁTIL, Jiří - LIN, Kevin - COX, Laurence. Movements in Post/ Socialisms. Editorial. In Interface: a Journal for and about Social Movements, 2015, Vol. 7, No. 2, pp. 1-8; PICHARDO, Nelson A. New Social Movements: A Critical Review. In Annual Review of Sociology, 1997, No. 23, pp. 411-430.

3 WALLERSTEIN, Immanuel. World-systems Analysis: An Introduction. Durham, NC : Duke University Press, 2004. For a summary of the current debates on postsocialist Europe, see the review essay: BIELSKA, Beata - WROBLEWSKI, Michał. Central-Eastern Europe as Postcolonially Involved (Sub)peripheries. Giordano Christian, 2015. Power, Legitimacy, Historical Legacies: A Disenchanted Political Anthropology, Wien, LIT VERLAG. In Eastern European Countryside, 2017, No. 23, pp. 209-220, DOI: 10.1515/eec-2017-0010.
} 
from different geographical contexts. This played a large role in the mobilisation against what those involved perceived as neoliberal globalisation. ${ }^{4}$ Furthermore, the topics of radical geography and cartography were regarded by many as synergic to the main quests of the anti- or alter-globalisation movement, hijacking globalisation for its own purposes. ${ }^{5}$

This paper emerges at the end of the decade following the 2008 crisis, at a time when the global conservative right have managed to successfully incorporate the struggle against globalisation into their nationalist agendas. The primary research goal here is to classify and analyse the geographical terms used in the anarchist press in the context of the heightened globalisation debate of the early 2000s. The aim is thus to open up the discussion based on qualitative research in order to examine the interconnectedness of different struggles at a local level. This is made possible due to the selection of a relatively small sample of two journals published in the early 2000s in Slovakia. When analysing the sample, semantic analysis was employed in order to provide pertinent answers to the central research question. The aim of this study is to provide a classification of geographical categories based on how they operate in the anti-globalisation activist press. A hypothesis may be formulated that geographical references play several crucial roles in this movement, where the dichotomy between the global and the local is of central importance. I have chosen Slovakia as an illustrative example due to the expected fragmentary results.

In terms of (fan)zines and the DIY press, readers should be made aware of the specificities of how such an activist press operates. ${ }^{6}$ It should further be noted that the anti-globalisation movement also involved other types of actors from political currents that cannot easily be labelled as anarchist. In the anti-globalisation camp, one could also easily find (post)autonomists, certain mouthpieces of the syndicalist movement, sympathisers of the radical left and third-worldists. This "multitude" partly adopted the "alter-globalist" credo of "another world is possible".

4 AYRES, Jeffrey. Framing Collective Action Against Neoliberalism: The Case of the "Anti-Globalization" Movement. In Journal of World-systems Research, 2004, Vol. 10, No. 1, Special Issue: Global Social Movements Before and After 9-11, pp. 11-34; HARVEY, David. A Brief History of Neoliberalism. Oxford, UK : Oxford University Press, 2005. Notes from: NOWHERE (eds.) We Are Everywhere: The Irresistible Rise of Global Anticapitalism. London; New York : Verso 2003.

5 ORANGUTANGO (eds.) This is not an Atlas. A Global Collection of Counter-geographies. Bielefeld : transcript, 2018; SPRINGER, Simon. Anarchism and Geography: A Brief Genealogy of Anarchist Geographies. In Geography Compass, 2013, Vol. 7, No. 1, pp. 46-60, DOI 10.1111/gec3.12022; see also the thematic issue of Antipode edited by Simon Springer: Antipode: A Radical Journal of Geography, 2012, Vol. 44, No. 5, pp. 15791754.

6 ANDERSON, Benjamin. Rising Above: Alternative Media as Activist Media. In Stream: Culture/Politics/ Technology, 2015, Vol. 7, No. 1, pp. 23-33; JEPPESEN, Sandra. Becoming Anarchist: The Function of Anarchist Literature. In Anarchist Developments in Cultural Studies. Art \& Anarchy, 2011, No. 2, pp. 189-213; LIEVROUW, Leah A. Alternative and Activist New Media. Cambridge; Malden, MA : Polity Press, 2011.

7 BIRKNER, Martin - FOLTIN, Robert. (Post-)Operaismus: Von der Arbeiterautonomie zur Multitude. Stuttgart : Schmetterling, 2010; BLEIKER, Roland. Politics After Seattle: Dilemmas of the Anti-Globalisation Movement. In Cultures \& Conflits, 2002, http://journals.openedition.org/conflits/1057; ESCHLE, Catherine. Constructing "the anti-globalisation movement". In International Journal of Peace Studies, 2004, Vol. 9, No. 1, pp. 61-84; ROHRBACHER, Tomáš. Střet diskursů: zhodnocení aktivit antiglobalizačního hnutí v uplynulých deseti letech. Working papers Fakulty mezinárodních vztahủ Vysoké školy ekonomické v Praze, 2011, Vol. 5, No. 3; WARNER, Adam. A Brief History of the Anti-Globalization Movement. In University of Miami International and Comparative Law Review, 2005, Vol. 12, No. 237, pp. 237-268. See also the programmatic text of the anti-globalization movement, which called attention to new forms of domination after the Cold War 
With the far right's history of anti-globalisation positions already in the early 2000s, nationalists and right-wing populists have been successfully critiquing globalisation since 2008, namely by harnessing the mobilising potential of the economic crisis. ${ }^{8}$ Other fringes of the anti-globalisation movement experienced a revival in the early 2010s during times of austerity, with Greece serving as the most striking example. ${ }^{9}$

The position of Slovakia at the turn of the millennium was neither at the core nor at the periphery of the capitalist world-system. Based in the successor country of former Czechoslovakia, Slovak anarchists naturally saw themselves as a part of the above-mentioned global movement, though they maintained particularly strong ties to activists from the Czech territory. ${ }^{10}$ Some articles in the activist press published in Slovakia were edited in the Czech language and the relatively freely interchangeable language strategies were also observed among Czech activists. ${ }^{11}$ The other perceived idiosyncrasies can be attributed to the post-socialist context. The first decade after the fall of the bureaucratic socialist regime also heralded an unprecedented geographical openness for both successor countries of former Czechoslovakia, and it was the youngest activist generation in particular which benefited from this openness. On the other hand, the post-socialist context spurred fervent anticommunism among many activists who would likely have identified with the left elsewhere in the world. For many young activists, the difficulty of coping with the legacy of communism meant the organic embracement of anarchism, which served as a libertarian but still anti-capitalist antidote to Marxism-Leninism. ${ }^{12}$ Another key element pertaining to the post-socialist context of Central Eastern Europe and the rise in racist violence was antifascism. ${ }^{13}$

and the "multitude" of actors capable of forming an opposition: HARDT, Michael - NEGRI, Antonio. Empire. Cambridge, MA; London : Harvard University Press, 2000 and the "multinationals" as key actors in a new type of brand-based consumerism: KLEIN, Naomi. No Logo: Taking Aim at the Brand Bullies. Hammersmith; London : Flamingo, 2000. The proximity of the anti-globalization movement can also be detected in the documentaries of Michael Moore, in particular The Big One (1997) and Capitalism: A Love Story (2009). 8 BELK, Russell. Collective Narcissism, Anti-Globalism, Brexit, Trump, and the Chinese Juggernaut. In Markets, Globalization \& Development Review, 2017, Vol. 2: No. 3, pp. 1-8, DOI 10.23860/MGDR-2017-02-03-02.

9 See e.g.: MEZZADRA, Sandro. In the Wake of the Greek Spring and the Summer of Migration. In The South Atlantic Quarterly, 2018, Vol. 117, No. 3, pp. 925-933, DOI 10.1215/00382876-7166092; PEREZ, Sofia A. - MATSAGANIS, Manos. The Political Economy of Austerity in Southern Europe. In New Political Economy, 2017, Vol. 23, No. 2, pp. 192-207, DOI 10.1080/13563467.2017.1370445 or the activist documentary Ne vivons plus comme des esclaves by Yannis Youlountas, France and Greece, 2013.

10 For Czech-based receptions of the global movement, see: KOLÁŘOVÁ, Marta. Protest proti globalizaci: gender a feministická kritika. Praha : SLON, 2009.

11 DANIEL, Ondřej. "Speaking in a Language They Understand": Development of Czech and Slovak Antifascism in the Post-socialist Years. Manuscript in review for Fascism. Journal of Comparative Fascist Studies, special issue: "Global Cultures of Antifascism, 1920-2016."

12 For the Czech context (probably not entirely valid in Slovakia), see: HANLEY, Séan. The New Right in the New Europe. Czech Transformation and Right-wing Politics, 1989 - 2006. London; New York : Routledge, 2008. For reflections of activists themselves, see: JANA (podl'a materiálov ORA Solidarita). Socializmus zdola v Ruskej revolúcii. In Zdola, 2002, No. 5, January, p. 10.

13 KELLER, Mirja, KÖGLER, Lena, KRAWINKEL, Moritz, SCHLEMERMEYER, Jan. Antifa: Geschichte und Organisierung. Stuttgart : Schmetterling 2018. For the antifascism reflected in the primary material: -vg-. Správy z domova. In Zdola, 2001, No. 4, August, p. 3; DANIEL, Fero. Začína to nevinne. In Zerme bohatých, 2002, No. 4, December, p. 5. 


\section{Sources}

The primary materials for this study were retrieved with the help of Lidiap (List of digitised anarchist periodicals), ${ }^{14}$ an internet-based repository of freely accessible digitised anarchist journals/newspapers administered by the Berlin-based Bibliothek der Freien. ${ }^{15}$ The two journals can be considered as representing different ideologies. While both can be described as anarchist, there are perceptible differences between the two. The first, Zdola ("From the Bottom"), was published by the Slovak section of the Czechoslovak Anarchist Federation (ČSAF) ${ }^{16}$ and can be described by its relatively unproblematic acceptance of the anti-globalisation movement. Although it represented a much larger and arguably more important territory, the Slovak section was presented by the ČSAF as being at the same level as that of Moravia, Central, Eastern or Southwestern Bohemia. ${ }^{17}$

Eight regular and three special issues from the period August 2000 - January 2004 were retrieved and analysed for this paper. ČSAF has been a member of the International of Anarchist Federations (known as "IAF") since 2003. Politics were prioritised over lifestyle, which was first reflected in Zdola (6/2003) in critiques of the undignified behaviour of "Alco-punks" at manifestations and other mobilisations. Furthermore, the signatures or acronyms of the authors started to appear with increasing frequency, something which had been virtually unseen in the past. There was also notable overlap with the positions of the radical left, in particular in the reprint of a Slovak translation of an article written by Le monde diplomatique editor-in-chief Ignacio Ramonet by the leftist web journal Nové slo$v o .{ }^{18}$ The trend of the leftist internationalisation of the Slovak section of ČSAF was, however, already reversed in the following edition of Zdola (7/2003). This took the form of two pages almost exclusively dedicated to local topics, with the sole exception of contextualising the May Day tradition of the USA. ${ }^{19}$

\begin{tabular}{lllll|}
\hline ČSAF Slovensko & ČSAF střed & ČSAF Morava & ČSAF východ & ČSAF jihozápad \\
\hline ČSAF & ČSAF & Vladimír Futák & Pavel Houdek & ČSAF \\
Poste restante & P.O. BOX 223 & Smetanova 3 & P.O. BOX 41 & P.O. BOX 40 \\
851 06 Bratislava 57 & 11121 Praha 1 & 75000 Přerov & 56501 Choceň & 385 01 Vimperk \\
csaf_sk@hotmail.com & praha@csaf.cz & morava@csaf.cz & vychod@csaf.cz & jihozapad@csaf.cz
\end{tabular}

Figure 1. Czechoslovak Anarchist Federation contacts, June 2001. (Source: author's archive)

14 An English version of the website can be found at https://www.bibliothekderfreien.de/lidiap/eng/ stating, "Magazines/Newspapers are included in Lidiap if they fulfill [sic] the criterion sanarchist according to the regulations of Datenbank des deutschsprachigen Anarchismus - Pressedokumentation (Database of German Language Anarchism - Press Documentation). They are available for free download (i.e. free of charge and without registration) on the internet, preferably in pdfformat. There are no restrictions in regards to language, place or year of publication."

15 Anarchistische Bücherei im Haus der Demokratie, Greifswalder Str. 4, 2. Hof, Raum 1102, 10405 Berlin (Prenzlauer Berg), Germany.

16 LINHARTOVÁ, Lucie. Československá anarchistická federace. MA thesis. Praha : Univerzita Karlova v Praze, Fakulta sociálních věd, 2014.

17 For example contacts in a special issue of Zdola, "Street party in Bratislava", 9. June 2001, p. 4.

18 RAMONET, Ignacio. Sociálna vojna. In Zdola, 2003, No. 6, January, p. 4.

19 -mh-. Historické koreně tradície 1. mája. In Zdola, 2003, No. 7, May, p. 1. 
The second journal, Žerme bohatých (ŽB, "Let's eat the rich") was published by the organisation Priama akcia ("Direct action"), which labelled itself as the Slovak section of the International Workers' Association. Following the division of the anarchist movement, as identified by Murray Bookchin, ${ }^{20}$ ŽB promoted social anarchism, or more accurately anarcho-syndicalism, with a deeper focus on local struggles, such as Slovak strikes in the railway and education sectors. However, ŽB also reported on strikes and syndicalist struggles from around the world. The sample used in this study includes three regular and three special issues from the period December 2002 - August 2003, i.e. from the period following the zenith of the anti-globalisation movement. Distant echoes of the movement can be observed by the use of the motto "Think locally, act globally", reprinted in the special issue of ŽB dedicated to the 2003 railway strike in Slovakia. ${ }^{21}$ It is also worth noting that the ŽB special issue "Strike in the education sector" of June 2003 provided no geographical references whatsoever.

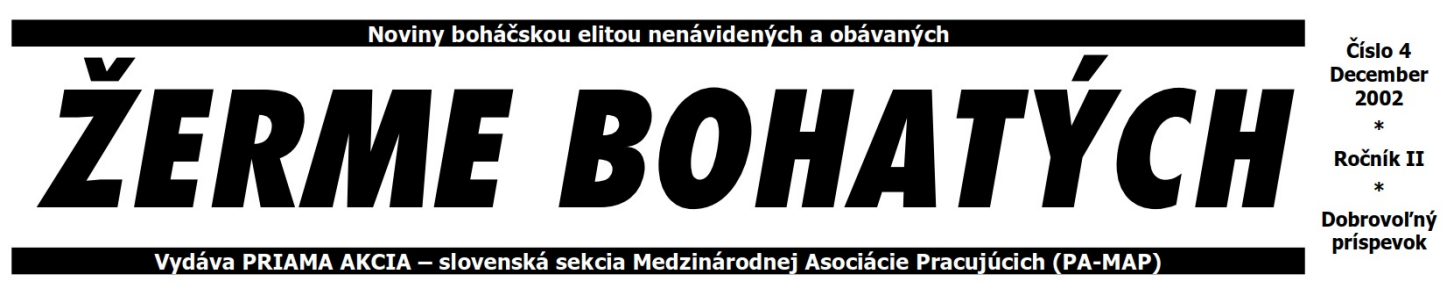

Figure 2. Žerme bohatých heading, December 2002: "Let's eat the rich, newspaper of those hated and feared by the rich elite". (Source: author's archive)

For the sake of this study, I propose the following classification of geographical references gleaned from the two journals:
1. Action!
2. Strike
3. Empire
4. South
5. Roots

Of course, most of these categories are fluid and some of the obtained information could be allocated to more than one category. In addition, there are several geographical references which did not fit in with any of the classifications. Hyperboles and similes are examples of such outliers, such as "In Prague there was Kosovo", 22 referring to the violence in the streets during the protests of September 2000. Furthermore, the denomination of the "Soviet Union" was not employed in geographical terms, but rather referred to the oppressive political system based on the hegemony of the Stalinist party. ${ }^{23}$

20 BOOKCHIN, Murray. Social Anarchism or Lifestyle Anarchism: the Unbridgeable Chasm. San Francisco; Edinburgh : AK Press, 1995.

21 Ako sa organizovat'? In Žerme bohatých (Špeciálne vydanie), 2003, January, p. 2.

22 DROBEC. Názory. In Zdola, 2000, No. 2, October, p. 10.

23 NATO? Nie, d’akujem. In Zdola (Špeciálne vydanie), 2002, Summer, p. 1. 


\section{Action!}

References about manifestations and interventions, including local ones, such as May Day, street parties, picketing and the dissemination of leaflets, can all be included in the same category. The special issue of $Z$ dola published for a street party in Bratislava on 9. June 2001 generated reports about May Day venues around the world and was particularly fruitful in this regard. Capitals of countries close to Slovakia were highlighted, such as Prague, Warsaw, Vienna and Berlin. Furthermore, important centres for the May Day 2001 events in Europe were listed, including Amsterdam, Dublin, London and Athens. Finally, overseas destinations were also mentioned: Seoul and information compiled from different cities in Australia and the USA was included in the same report.

Detailed information about the manifestations against economic globalisation during the meeting of the World Bank and International Monetary Fund leaders that took place in September 2000 in Prague proved to be the most important and prominent geographical reference. Prior to the manifestations, mobilising information on the Prague-based coalition of various protest groups, named INPEG (Inicativa proti ekonomické globalizaci, "Initiative against economic globalisation"), was diffused in Zdola. ${ }^{24}$ The following issue provided a detailed report from the protests in Prague, ${ }^{25}$ which was contextualised with respect to other localities of anti-globalisation mobilisation, such as Seattle, Melbourne, Washington, Florence or those anticipated in the Alpine resort of Davos. The special issue of Zdola for the street party in Bratislava in June 2001 also called on readers to attend future events in Prague, Gothenburg, Barcelona and Salzburg. ${ }^{26}$ The following issue of Zdola yielded reports from protest events in Gothenburg and Genoa. ${ }^{27}$

Reports from Prague and Genoa often discussed the issue of police violence. The primary problem in Prague was the mistreatment by police of those arrested during the violent portion of the manifestations. ${ }^{28}$ As of July 2001, police violence and the violent repression of the demonstrations in Genoa became a widely discussed topic. Genoa became a symbol of state repression against a variety of forms and strands of the anti-globalisation movement. ${ }^{29} \mathrm{Zdola}$ had a honed focus on covering the protests in Genoa. ${ }^{30}$ An emblematic turning point was when the police killed protester Carlo Giuliani, resulting in manifestations of solidarity in Prague and Bratislava. ${ }^{31}$ Furthermore, ŽB published direct testimonials from Genoa. ${ }^{32}$ Depictions of police violence during the anti-globalisation protests were frequently

\footnotetext{
24 INPEG - Praha 2000. In Zdola, 2000, No. 1, August, pp. 1-3.

25 INPEG - Praha 2000. In Zdola, 2000, No. 2, October, pp. 4-10.

26 Advertisment in Zdola (Špeciálne vydanie), 9. June 2001, p. 3.

27 MARTIN. Goteborg a Janov - ako d’alej? alebo dôvod na zamyslenie. In Zdola, 2001, No. 4, August, pp. 8-9.

28 -pb-. Policajná prax - výpoved' zadržaného člena ČSAF. In Zdola, 2000, No. 2, October, p. 10.

29 ANONYMOUS EDITORS. On Fire. The Battle of Genoa and the Anti-capitalist Movement. London : One-off Press, 2001.

30 -vg- - JANA. Správy zo zahraničia. In Zdola, 2001, No. 4, August, p. 4.

31 -vg-. Správy z domova. In Zdola, 2001, No. 4, October, p. 3.

32 Svedectvo z protestovv Janove. In Žerme bohatých, 2001, No. 1, p. unknown, reference in the advertisement of past issues in Žerme bohatých (Špeciálne vydanie), 2003, No. 2, January, p. 2.
} 


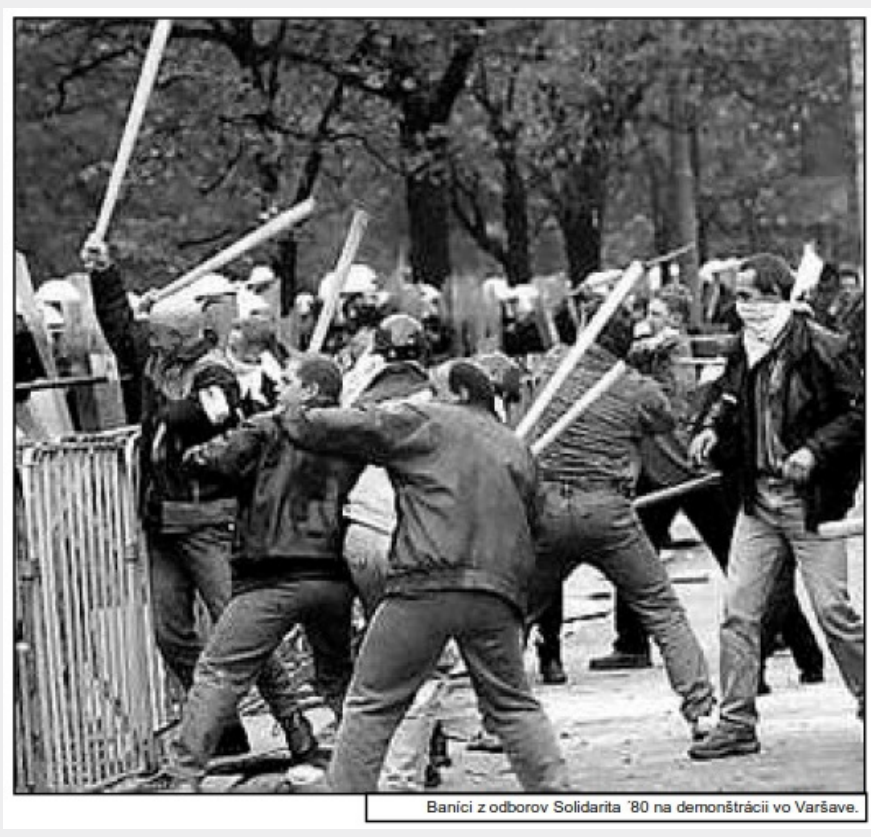

Figure 3. Protesting miners of the Solidarity 80 trade union, Žerme bohatých, 2002, No. 4, December, p. 1. (Source: author's archive)

reflected even in mainstream cinematography, with movies such as Battle in Seattle (2007) and Diaz - Don't Clean Up This Blood (2012).

It is evident that anti-globalisation protesters were not always peaceful, as some took to the streets well prepared for clashes with the police. I have argued elsewhere that such a spectacular police presence with an electrifying atmosphere, reminiscent of "states of emergency", carefully documented and diffused with "riot porn", was a key element in fuelling the violent ecstasies of such fringes of protesters. ${ }^{33}$ Furthermore, the repressive state apparatus often failed in differentiating violent and non-violent protesters and, given the bitter experiences with police violence, it was with a certain satisfaction that ŽB published a report on the repression of the police strike in Madrid with the headline "When cops beat cops". ${ }^{34}$

\section{Strike}

Other types of actions and activities stemmed from the syndicalist tradition and received ample attention in ŽB in particular. Zdola also presented information about the struggles of workers, such as the workers' blockade of a shutdown cable-manufacturing plant in Ozarów (Poland). ${ }^{35}$ ŽB merged the aesthetics of "riot porn" with the agenda of workers' struggles by publishing a picture of protesting miners of the Solidarity 80 trade union attacking the police. The journal also covered protests against the closure of the ironworks in Laziska near the Silesian town of Tychy (Poland). ${ }^{36}$ The same issue of ŽB also covered the workers' struggles in the Rydygiera hospital in Wroclaw and the Szczecin shipyards. In addition to Poland, a country geographically close to Slovakia but with a radically different tradition of workers' struggles, ŽB reported closely on the general strike in Italy. ${ }^{37}$ In this context, the journal largely sympathised with the grassroots unions

33 DANIEL, Ondřej. "Wildlife". Ecstatic practices of hardcore football and extreme music fans during the Czech and Slovak post-socialism. In Český lid, 2019, No. 106, p. 69-83. See also: RAZSA, Maple John. Beyond "Riot Porn": Protest Video and the Production of Unruly Subjects. In Ethnos: Journal of Anthropology, 2013, Vol. 79, No. 4, pp. 1-29, DOI:10.1080/00141844.2013.778309.

34 Ked' fízel bije fízla. In Žerme bohatých, 2002, No. 4, December, p. 6.

35 -pt-. Krátke správy. In Zdola, 2003, No. 6, January, p. 2.

36 Pol’ský hospodársky zázrak v ruinách. In Žerme bohatých, 2002, No. 4, December, p. 2 and 6.

37 Talianski radoví odborári v generálnom štrajku! In Žerme bohatých, 2002, No. 4, December, p. 2 
(comittati di basi) against the reformist and centralist Italian General Confederation of Labour (Confederazione Generale Italiana del Lavoro, known as “CGIL”).

ŽB also informed readers of several other workers' struggles around the world, often in the form of short notices. In March 2003 it published reports about such geographically diverse activities as the wild strikes in Canada, repression of the tram drivers' strike in Prague, protests of workers of the French Newell factory in Nègrepelisse against offshoring initiatives, Belgium strikers taking their boss hostage and the violence of strikers at the Doosan factory in Changwon, South Korea. ${ }^{38}$ A special 2003 issue of ŽB dedicated to the railway strike in Slovakia revealed information about struggles in the railway sector around the world. Strikes in France, Netherlands, Germany, England, Korea, Scotland, Kenya, Israel, Sri Lanka and Nigeria were compared alongside the activities of strikers in the Slovak localities of Bratislava, Trnava, Trenčín, Piešt’any, Nové Mesto nad Váhom, Žilina, Banská Bystrica, Košice, Prešov, Vranov nad Toplou, Humenné and Trebišov. ${ }^{39}$ ŽB exhibited a similar narrative strategy of aligning international struggles with local ones as early as December 2002 in their coverage of the McDonald's Workers Resistance and solidarity actions in Banská Štiavnica, Trnava, Bratislava and Košice as well as in Great Britain, New Zealand, Italy, Germany, France, Russia, Mexico, Slovenia, Australia, Denmark, Spain, Sweden, Northern Ireland and Serbia. ${ }^{40}$

\section{Empire}

Further geographical references in the two journals related to places understood as the territory of the enemy. I have selected the term "Empire" to refer to the common denominator here. The above-quoted book by Michael Hardt and Antonio Negri became a widely accepted theoretical framework even for the anti-globalisation activists themselves. It considers the Empire to be a sum of practices carried out through the concept of deterritorialisation. Many such references, even if undoubtedly geographical, are thus not necessarily territorial. The World Trade Organisation (WTO), International Monetary Fund (IMF) and World Bank (WB) can serve as examples here.

Similarly, the activities of the Group of Seven (G7) were chided for intensifying global inequality, securing the power of rich countries and exploiting the poor. Both journals were also similarly critical of certain prominent G7 members the USA and to a certain extent also the European Union (EU). ${ }^{41}$ Zdola covered the protests against the EU summit in Gothenburg, summarising the message as one of "against Europe of corporations, against Europe stepping on human

38 -mt-. Z hlavných správ sa nedozvieš, že... In Žerme bohatých, 2003, No. 5, March, p. 2.

39 Boje železničiarov vo svete. In Žerme bohatých (Špeciálne vydanie), 2003, January, p. 2.

40 Zákaz odborov, stres, nízke mzdy. McDonald’s je skrátka fajn! In Žerme bohatých, 2002, No. 4, December, p. 4.

41 For a detailed analysis of European anti-Americanism, see: BEHRENDS, Jan C. - KLIMÓ, Arpad von POUTRUS, Patrice G. Antiamerikanismus im 20. Jahrhundert: Studien zu Ost- und Westeuropa. Bonn : Verlag J.H.W. Dietz Nachf., 2005. For the context of the left-wing oriented critic of the European Union, see: DURAND, Cedric (ed.) En finir avec l'Europe. Paris : Fabrique, 2013; or KOVAČEVIĆ, Nataša. Storming the EU Fortress: Communities of Disagreement in Dubravka Ugrešić. In Cultural Critique, 2013, Vol. 83, pp. 63-86. 
rights and closing itself vis-à-vis the refugees. ${ }^{\prime \prime 2}$ It also saw EU economic policies as protecting the interests of large corporations. ${ }^{43}$ Certain EU and G7 member states, such as Germany and France, were also criticised for merchandising military equipment. ${ }^{44}$ Another negative geographical reference in Zdola was that of the Vatican. ${ }^{45}$ In an issue focusing primarily on John Paul II's visit to Slovakia, the policies of the papal state were linked to the spread of AIDS in Africa due to Catholic restrictions on contraception.

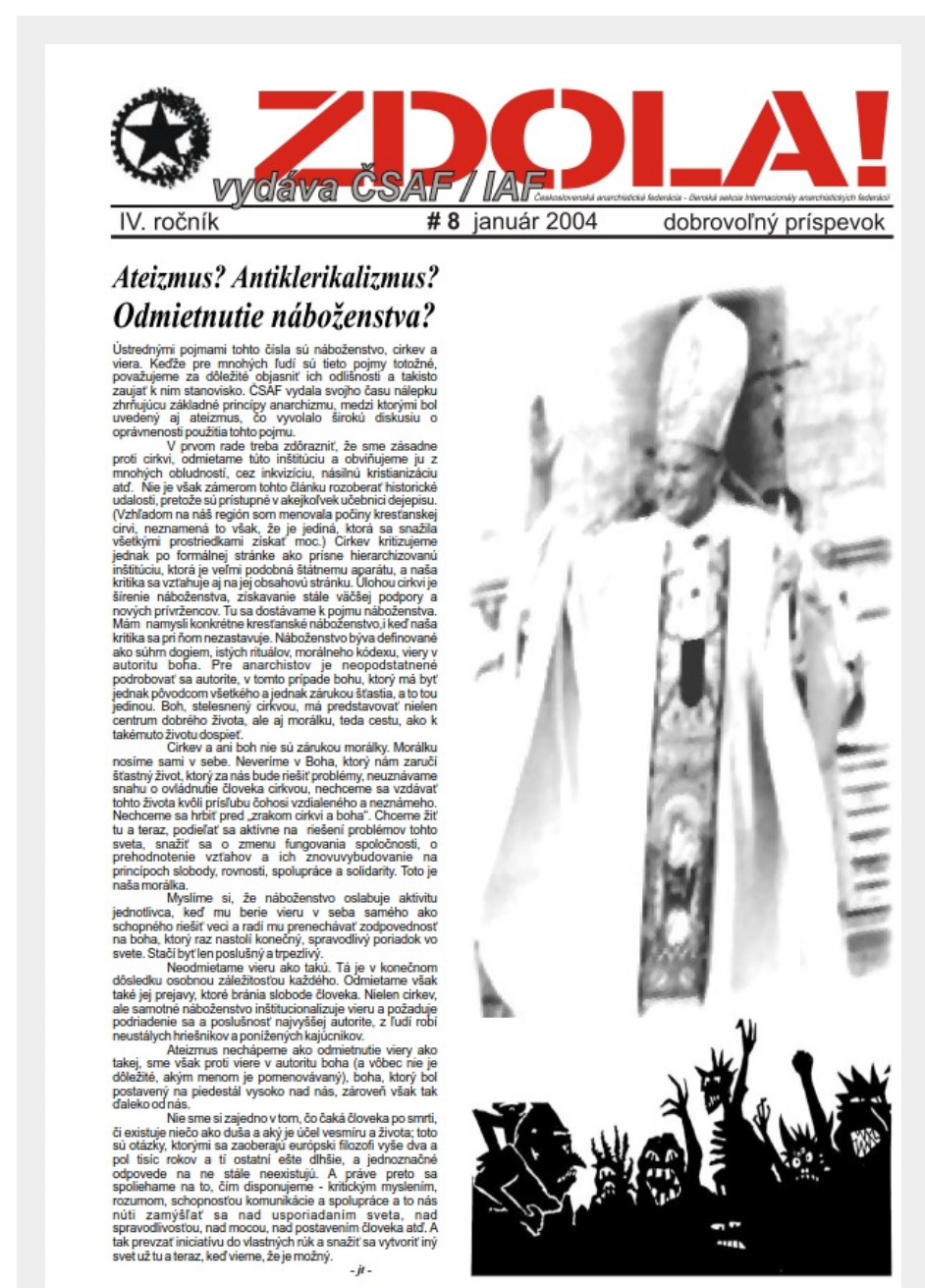

Figure 4. Zdola, 2004, No. 8, January. (Source: author's archive)
One of the geographical references that was often described as being antagonistic to anti-globalisation positions was that of NATO. Slovakia did not become a NATO member until 2004, five years later than Poland, Hungary and the Czech Republic. The neighbouring country of Austria remained neutral. In the early 2000s, the Slovak public debate surrounding NATO was a relatively heated one, with anarchist journals taking a firm anti-NATO stance. This was also evidenced in Zdola, which published a feature on NATO for its issue in August 2001. ${ }^{46}$ In January 2002 it also mobilised readers to rally against the NATO summit in Munich that was held the following month. ${ }^{47}$ Critiques of NATO were often made in connection with references to international conflicts.

These were undoubtedly conceived of as imperialist wars, and the critique of militarism can be seen as a critique of the Empire. A special issue of Zdola titled "Against war" understood "imperialist wars" as sine qua non: "There is no capitalism without wars. ${ }^{\prime 48}$ One of the international conflicts criticised in the anarchist press

\footnotetext{
42 -vg-, Jana. Správy zo zahraničia. In Zdola, 2001, No. 4, August, p. 4.

43 IUR. EÚ? Frázy, frázy, frázy... In Zdola, 2003, No. 6, January, p. 6.

44 Nie je kapitalizmus bez vojen! In Zdola (Špeciálne číslo proti vojne), 15. February 2003, p. 2.

45 -iur-. Pápež? Nepápem! In Zdola, 2004, No. 8, January, pp. 2-3.

46 Zdola, 2001, No. 4, August.

47 Proti NATO v Mnichove. In Zdola, 2002, No. 5, January, p. 9.

48 Nie je kapitalizmus bez vojen! In Zdola (Špeciálne číslo proti vojne), 15. February 2003, pp. 1-2.
} 
was the USA's involvement in Afghanistan. ${ }^{49}$ Zdola would later go on to criticise the Afghanistan mission for securing the interests of the US petrol corporation Unocal. ${ }^{50}$ A similar reference was made regarding Iraq, where a controversial USA-led coalition invaded the country in March 2003. ${ }^{51} \mathrm{Z} \mathrm{B}$, in its special issue titled "Let's eat the rich and their wars" reported on the "new maps of the world" that these missions were drawing. ${ }^{52} \check{Z} \mathrm{~B}$ also cited examples of the resistance against "imperialist wars", such as the blockade of the Darby military camp near Pisa (Italy). In Ireland, anti-war protesters blocked access to Shannon Airport. ${ }^{53}$

\section{South}

Many anti-globalisation activists understood the centres of the global Empire to be synonymous with the wealthy North and the powerful West. Their "spaces of hope", on the other hand, were often located in the global South. ${ }^{54}$ In this regard, the region of Zapatist Chiapas was the most referenced by the anti-globalisation activists. This was perceived by many to be a social experiment deserving of attention. The Slovak activist press often mentioned two Czech books about Chiapas. ${ }^{55}$ Zdola also presented picturesque visuals of masked Zapatistas in traditional clothing. ${ }^{56}$ In addition to Chiapas, several other struggles in the global South were highlighted, such as the movement of the landless MST (Movimento dos Trabalhadores Rurais Sem Terra) in Brazil, ${ }^{57}$ the strikes in San Salvador and Bolivia and other social struggles. ${ }^{58}$ It is up for debate as to whether or not the accounts of Saudi Arabia and Turkey can be assessed in tandem with the South. However, given the active involvement of these two countries in the practices of the Empire, the image they evoked was predominantly a negative one. ${ }^{59}$ This was primarily due to the negligence of human rights as well as the Kurdish movement, which attracted a number of sympathisers from anti-globalist camps.

A notable portion of the information on the struggles in the global South referred to Argentina, where local social movements organised a grassroots resistance against the budget cuts ordered by IMF after the country had gone bankrupt. ${ }^{60}$ The general issue of the countries indebted to the IMF as well as the possible

49 Prípad Afganistan. In Zdola (Špeciálne vydanie), 2002, Summer, p. 4.

50 SLAČÁLEK, Ondřej (ČSAF střed). Mýty a polopravdy o válce v Afghánistánu. In Zdola, 2002, No. 5, January, pp. 4-5.

51 Vojna v Iraku. 0 čo ide a ako ju ochromit'. In Žerme bohatých, 2003, No. 5, March, p. 1 and 6.

52 Vojna v Iraku vo faktoch. In Žerme bohatých (Špeciálne číslo), 2003, March, pp. 1-2.

53 TULÍK, Michal. Proti vojne boháčov a politikov! In Žerme bohatých (Špeciálne číslo), 2003, March, p. 1.

54 For a Marxist analysis of utopian spatiality under globalization, see HARVEY, David. Contemporary globalization. In HARVEY, David. Spaces of Hope. Edinburg : Edinburg University Press, 2000, pp. 53-72.

55 MÁCHA, Přemysl. Plamínek v horách, požár v nížině: indiánské povstání v mexickém Chiapasu. Brno : Doplněk, 2003; PEĆ́́NKA, Pavel. Od Guevary k zapatistům - přehled, složení a činnost gerilových hnutí Latinské Ameriky. Brno : Doplněk, 1998.

56 Zdola, 2001, No. 3, April, pp. 1-2; Zdola, 2003, No. 6, January, p. 2.

57 -mh-. Pôda je naša. In Zdola, 2000, No. 2, October, p. 11.

58 -mt-. Z hlavných správ sa nedozvieš, že... In Žerme bohatých, 2003, No. 5, March, p. 2.

59 NATO? Nie, d'akujem. In Zdola (Špeciálne vydanie), 2002, Summer, p. 1.

60 -vg-, Jana. Správy zo zahraničia. In Zdola, 2001, No. 4, August, p. 4; Správy. In Zdola, 2002, No. 5, p. 3; -mh-. Argentína rok po povstaní - nádeje a sklamania. In Zdola, 2003, No. 6, January, p. 2; TULÍK, Michal. Útok na železnice v d'alších štátoch. In Žerme bohatých, 2003, No. 5, March, p. 3. 
remission of debt fed sentiments of global injustice along with the mobilisation strategies of the anti-globalisation movement. Anti-globalization activists empowered their comrades from the global South to take a more active stance in global economic relations. They also considered the South to be a passive subject of the North-based Empire, and events such as the Kontrasummit in Prague ${ }^{61}$ or the 2001 World Social Forums ${ }^{62}$ were meant to balance this dependency.

The Slovak activist press also shed light on the interests and questionable practices of multinational corporations in countries of the global South, such as Shell in Nigeria or Oxy in Ecuador. Their activities were admonished for having a direct impact on ecological devastation and for suppressing workers' rights campaigns. ${ }^{63}$ As has been mentioned, Unocal was accused of establishing geopolitical interests in Afghanistan in order to secure an oil pipeline. ${ }^{64}$ In addition to the Southern references of the Nile Delta, Bangladesh and the rainforest, Zdola also highlighted the incidence of ecological devastation in the form of biotech and GMO contamination of the Danube and the Black Sea. The journal mentioned these pollutants in addition to the heavy metals and oil that polluted the river running from the north-west to the south-east, as well as the sea. ${ }^{65}$

The final set of references of this sort pertained to migration and refugee advocacy. Zdola understood state borders predominantly as separating the rich North from the poor South. ${ }^{66}$ Particular attention was paid to the history of the Schengen Area. ${ }^{67}$ It was also noted that territory agreements could be nullified from one day to the next, as exemplified by the efforts to repress the trans-frontier movement of anti-globalisation protesters to Genoa. ${ }^{68}$ The same Zdola issue also presented a report from an anti-racist festival in Athens supported by immigrant communities, published with a DIY computer image of the slogan "Crash fortress Europe". In regard to pro-migrant and pro-refugee activities, Zdola also covered the militant camp (called the "bordercamp") in Ustrzyki Górne, in the far south-east of Poland, close to the border with Ukraine and Slovakia. ${ }^{69}$ It also promoted the "No Border" network with its different "bordercamps" in Tarifa (southern Spain), Petišovci (southern Slovenia), Białystok/Krynki (eastern Poland) and Frankfurt am Oder (eastern Germany). ${ }^{70}$ Lastly, Zdola also published information about Australia's discriminatory migration policies and the migrant revolts in the country's detention centres. ${ }^{71}$

\footnotetext{
61 INPEG - Praha 2000. In Zdola, 2000, No. 2, October, p. 5.

62 SMITH, Jackie (ed.) Handbook on World Social Forum Activism. Oxon; New York : Routledge, 2016.

63 Globálny kapitalizmus. In Zdola (Špeciálne vydanie), 9. June 2001, p. 2.

64 Prípad Afganistan. In Zdola (Špeciálne vydanie), 2002, Summer, p. 4.

65 Globálny kapitalizmus. In Zdola (Špeciálne vydanie), 9. June 2001, p. 2.

66 Žiaden človek nie je ilegálny. In Zdola, 2000, No. 1, August, p. 6.

67 Martin. Trvalá sloboda? In Zdola, 2002, No. 5, January, p. 6.

68 -iur-. Totálna kontrola. In Zdola, 2004, No. 8, January, p. 8.

69 Žiaden človek nie je ilegálny. In Zdola, 2000, No. 1, August, p. 6.

70 noborder network. In Zdola, 2001, No. 4, August, p. 5.

71 -pt-. Krátke správy. In Zdola, 2003, No. 6, January, p. 2.
} 


\section{Roots}

Another set of geographical references alluded to international sister organisations and the places of origin of different activists as well as places important for anti-globalisation social movements. Zdola thus identified activists from the Slovak towns of Trnava, Košice and Prešov among the participants of the street party in Bratislava on 10. June 2000. ${ }^{72}$ One year later, however, the journal expressed dissatisfaction with the lack of activities outside of Bratislava. ${ }^{73}$ When reporting on the anti-WB and anti-IMF activities and the demonstrations that took place in Prague in September 2000, activists from Italy, Greece, Turkey, Brazil, India and Nicaragua were identified. ${ }^{74}$

Historical places that played a significant role in the anarchist movement, such as France in 1968, were also referred to ${ }^{75}$ It is important to note that Zdola did not

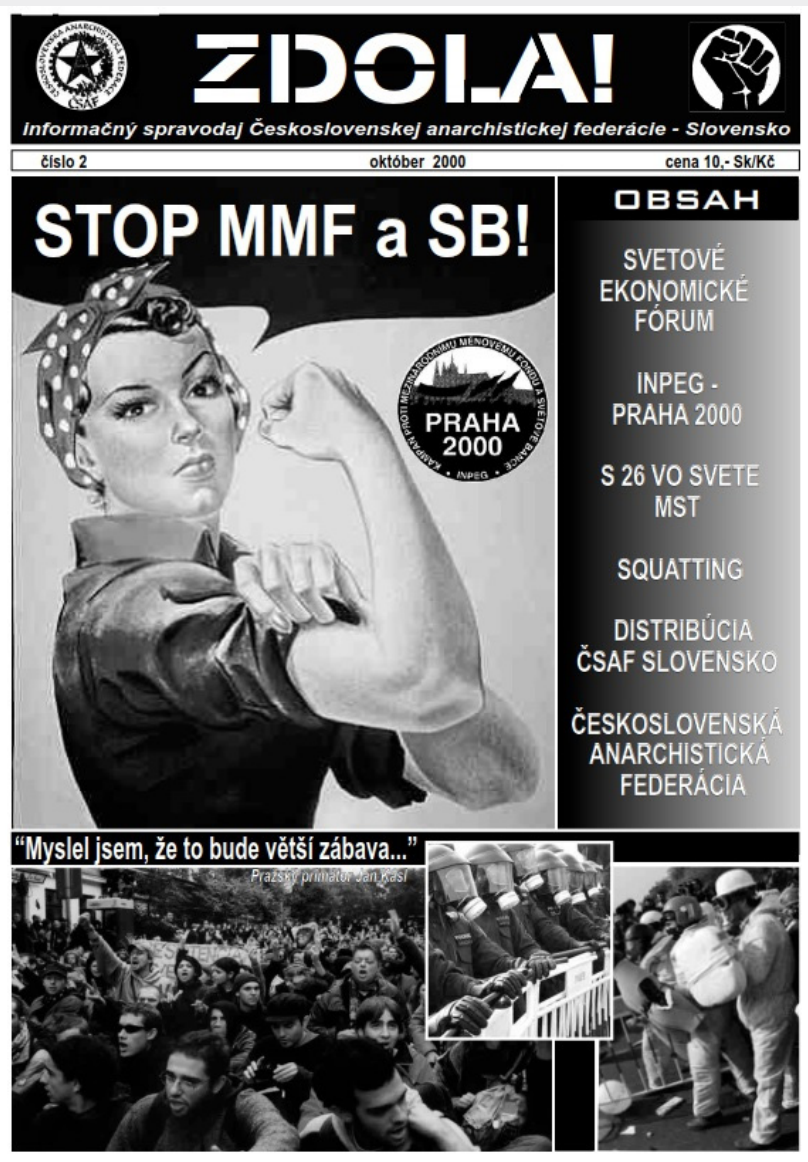

Figure 5. Zdola, 2000, No. 2, October. (Source: author's archive) limit its focus to the Latin Quarter in Paris as the crux of the student movement but also reported on occupied workplaces elsewhere in France, such as Sud Aviation in Nantes, Renault in Cléon and Flins, and the Peugeot factory in Sochaux. ${ }^{76}$ The historical experiences of anarchist Ukraine and Spain in the interwar period are further examples of those on the margins of history and geography. ${ }^{77}$ A rather specific mention in Zdola referred to an eco-anarchist experiment in Saskatoon (Canada). ${ }^{78}$

Other such references were made to squats as centres of anti-globalisation activities. Squatting in Bratislava took the shape of two significant but rather short-lived examples, one in Lodná, another in Podtatranská Street. ${ }^{79}$ Beyond the Slovak capital, important refe-

72 HORVÁTH, Martin. Bratislava 10. 6. In Zdola, 2000, No. 1, August, p. 4.

73 JANA. Editorial. In Zdola, 2001, No. 3, April, p. 2.

74 INPEG - Praha 2000. In Zdola, 2000, No. 2, October, pp. 5-6.

75 This was a crucial historical reference, and in many cases anti-globalization activists consciously followed the Situationist examples of the 1968 mobilization. See e.g.: DARK STAR (ed.) Beneath the Paving Stones. Situationists and the Beach. May 1968. Edinburgh; San Francisco : AK Press 2001.

76 -vg-. Tradícia boja - Paríž '68. In Zdola, 2001, No. 4, August, p. 6-7.

77 Iná možnost'. In Zdola (Špeciálne vydanie), 2002, Summer, p. 3.

78 TULÍK, Michal. Ekoanarchizmus očami Grahama Purchase. In Zdola, 2002, No. 5, January, p. 14.

79 Obsadený dom v Bratislave. In Zdola, 2000, No. 2, October, p. 12. 
rences to places central to the anti-globalisation movement were made to the nearby city of Vienna, where Ernst Kirchweger-Haus (so-called "EKH") ${ }^{80}$ as well as several other infoshops and bookstores, such as Anarchistische Buchhandlung in Hahngasse Street, were located. ${ }^{81}$ Vienna, due to its geographic proximity and myriad of active social movements, was an important reference in the Slovak anarchist press. Another example was that of Rosa Antifa Wien, an activist strand focused on anti-sexism, which was a rather new discovery for Slovak activists. ${ }^{82}$ From other neighbouring countries, squats in Prague, Krakow and Wroclaw were also mentioned. ${ }^{83}$

\section{Conclusion}

Geographical references in the Slovak anarchist press around the turn of the millennium provided potentially isolated activist communities with information about relevant struggles around the world. These references empowered these communities by calling on them to be a part of the global struggle. I would now like to analyse the gleaned references based on the functions they served in the two journals. I propose that a comparison of the geographical references be made with respect to the following narrative strategies employed by the journals:

1. Context

2. Equation

3. Inspiration

As noted above, providing local activists with context was one of the main functions of the geographical references published in the two journals. The differences between them stem from their different ideological profiles, with Zdola being comparatively less interested in the syndicalist tradition and ŽB focusing slightly less on other types of geographical references.

Table 1.

\begin{tabular}{|l|l|l|l|}
\hline & Context & Equation & Inspiration \\
\hline Action! & $\begin{array}{l}\text { Zdola: often } \\
\text { ŽB: sometimes }\end{array}$ & $\begin{array}{l}\text { Zdola: sometimes } \\
\text { ŻB: rarely }\end{array}$ & $\begin{array}{l}\text { Zdola: sometimes } \\
\text { ŹB: rarely }\end{array}$ \\
\hline Strike & $\begin{array}{l}\text { Zdola: rarely } \\
\text { ŽB: often }\end{array}$ & $\begin{array}{l}\text { Zdola: rarely } \\
\text { ŽB: often }\end{array}$ & $\begin{array}{l}\text { Zdola: rarely } \\
\text { ŻB: often }\end{array}$ \\
\hline Empire & $\begin{array}{l}\text { Zdola: often } \\
\text { ŽB: sometimes }\end{array}$ & $\begin{array}{l}\text { Zdola: sometimes } \\
\text { ŽB: sometimes }\end{array}$ & $\begin{array}{l}\text { Zdola: sometimes } \\
\text { ŽB: rarely }\end{array}$ \\
\hline South & $\begin{array}{l}\text { Zdola: often } \\
\text { ŽB: sometimes }\end{array}$ & not applicable & $\begin{array}{l}\text { Zdola: sometimes } \\
\text { ŽB: sometimes }\end{array}$ \\
\hline Roots & $\begin{array}{l}\text { Zdola: often } \\
\text { ŽB: sometimes }\end{array}$ & $\begin{array}{l}\text { Zdola: sometimes } \\
\text { ŽB: sometimes }\end{array}$ & $\begin{array}{l}\text { Zdola: sometimes } \\
\text { ŽB: sometimes }\end{array}$ \\
\hline
\end{tabular}

8010 rokov EKH. In Zdola, 2000, No. 1, August, p. 7.

81 Krátke správy. In Zdola, 2001, No. 3, April, p. 3.

82 Rosa Antifa Wien. In Zdola, 2002, No. 5, January, p. 12.

83 Bývanie je právo! In Zdola, 2000, No. 2, October, p. 13. 
Another narrative pattern was that of the equation, i.e. likening local cases to those reported on. With a comparatively low number of manifestations and strikes organised in Slovakia, both journals followed the ideological patterns identified above. Both journals drew parallels between some of the practices of the Empire and the Slovak context, in particular regarding Slovakia's path to NATO membership. One step beyond equation lies inspiration, drawn from practices attributed to the geographical references in order to transpose them to a local context. Once again, we can observe certain differences here between both journals based on their ideological differences.

Given the relatively small size of the Slovak population as well as the rather limited local tradition of anarchism and social struggles, geographical references likely played a crucial role in shaping the worldview of the country's anti-globalisation activists. The qualitative research presented in this article has allowed for a semantic categorisation of these references. Machine reading could further assist in providing new insights into the qualitative weight of the different references between the narratives. Additionally, the retrieved geographical references could be visualised so as to furnish future research with a valuable starting point.

Cituj:

DANIEL, Ondřej. Places of Revolt: Geographical References in the Slovak Anarchist Press Around the Turn of the Millennium. In Forum Historiae, 2020, Vol. 14, no. 1, s. 39-52. ISSN 13376861. DOI: https://doi.org/10.31577/forhist.2020.14.1.4

Mgr. Ondřej Daniel, Ph.D.

Seminář obecných a komparativních dějin

Ústav světových dějin Filozofická fakulta Univerzity Karlovy

Nám. Jana Palacha 2

11638 Praha 1, Česká republika

Email: ondrej.daniel@ff.cuni.cz 